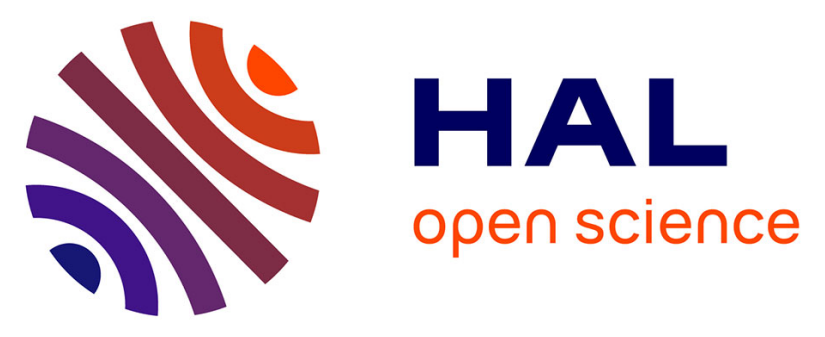

\title{
Implication of plant-soil relationships for conservation and restoration of copper-cobalt ecosystems
}

\author{
Michel-Pierre Faucon, Soizig Le Stradic, Sylvain Boisson, Edouard Ilunga Wa \\ Ilunga, Maxime Séleck, Bastien Lange, Delhaye Guillaume, Mylor Shutcha, \\ Olivier Pourret, Pierre Meerts, et al.
}

\section{To cite this version:}

Michel-Pierre Faucon, Soizig Le Stradic, Sylvain Boisson, Edouard Ilunga Wa Ilunga, Maxime Séleck, et al.. Implication of plant-soil relationships for conservation and restoration of copper-cobalt ecosystems. Plant and Soil, 2016, 403 (1-2), pp.153-165. 10.1007/s11104-015-2745-5 . hal-02265594

\section{HAL Id: hal-02265594 \\ https://hal.science/hal-02265594}

Submitted on 10 Aug 2019

HAL is a multi-disciplinary open access archive for the deposit and dissemination of scientific research documents, whether they are published or not. The documents may come from teaching and research institutions in France or abroad, or from public or private research centers.
L'archive ouverte pluridisciplinaire HAL, est destinée au dépôt et à la diffusion de documents scientifiques de niveau recherche, publiés ou non, émanant des établissements d'enseignement et de recherche français ou étrangers, des laboratoires publics ou privés. 


\section{Implication of Plant-soil Relationships for Conservation and Restoration of}

\section{Copper-cobalt Ecosystems}

Authors: Michel-Pierre Faucon ${ }^{1}$, Soizig Le Stradic ${ }^{2}$, Sylvain Boisson ${ }^{2}$, Edouard Ilunga wa Ilunga ${ }^{2,3}$, Maxime Séleck $^{2}$, Bastien Lange ${ }^{1,4}$, Delhaye Guillaume ${ }^{4}$, Mylor Ngoy Shutcha ${ }^{3}$, Olivier Pourret ${ }^{1}$, Pierre Meerts ${ }^{4}$, Grégory Mahy $^{2}$

${ }^{1}$ Hydrogeochimical Interactions Soil-Environment (HydrISE) Unit, Institut Polytechnique LaSalle Beauvais (ISAB-IGAL), 15 rue Pierre Waguet, Beauvais 60026, FR

${ }^{2}$ Biodiversity and Landscape Unit, Biosystem Engineering Department (BIOSE), University of Liège, Gembloux Agro-Bio Tech, 2 Passage des Déportés, Gembloux 5030, BE

${ }^{3}$ Ecology, Restoration Ecology and Landscape research Unit, Faculty of Agronomy, University of Lubumbashi, Lubumbashi, D.R. Congo

${ }^{4}$ Laboratory of Plant Ecology and Biogeochemistry, Université Libre de Bruxelles, 50

Avenue F. Roosevelt, BE-1050 Brussels, BE

*To whom all correspondence should be addressed. E-mail: michel-pierre.faucon@ lasalle-beauvais.fr

\section{Abstract}

Background: Chemical soil factors play an important role in generating and maintaining plant diversity. Naturally metal-enriched habitats support highly distinctive plant communities consisting of many rare and endemic species. Species of these plant communities possess remarkable physiological adaptations and are now being considered key elements in the implementation of green technologies aimed at phytoremediation of contaminated soils and post-mined soils. Several studies have emphasised that industrial mineral extraction results in serious damage to ecosystems and serious threats to human health and leads to the extinction of metallophyte species. In the southeastern Democratic Republic of the Congo (DRC), mining activities represent 
a threat to the long-term persistence of communities located on metalliferous copper and cobalt outcrops and their associated endemic metallophytes, which are currently considered some of the most critically endangered plants in the world.

33 Scope: Plant diversity conservation of metal-rich soils must assess soil-plant relationships at different scales (ecosystems, communities, and populations) to define in-situ and ex-situ conservation and restoration projects. This paper proposes a review of soil-plant relationships involved in plant diversity and endemism and their implications for biodiversity conservation and restoration.

37

38 Keywords: biodiversity conservation, chemical soil factors, endemism, heavy metals, metallophyte, restoration ecology, soil-plant interactions

40 


\section{Introduction}

For decades, ecologists have attempted to understand the relationships between soil properties and plant diversity, as some soils are associated with high richness and endemism in plant species (Whittaker et al. 2001; Escudero et al. 2015). A number of plant diversity hotspots are associated with nutrient-poor environments, notably in the Fynbos in South Africa, the Kwongan in southwestern Australia, and the Campos Rupestres in Brazil (Cowling and Lombard 2002; Hopper and Gioia 2004; Lambers et al. 2010; Laliberté et al. 2013; Lambers 2014; Silveira et al. 2015). Regions with naturally metal-rich soils may also exhibit landscape and environmental heterogeneity, promoting high richness and endemism in plant species, such as New Caledonia (Pillon et al. 2010), Sabah (Malaysia) (van der Ent et al. 2015a), California (USA) (Brady et al. 2005), Cuba (Borhidi 1996), and southeastern Democratic Republic of Congo (DRC) (Küper et al. 2004; Faucon et al. 2010). The most widespread natural metalliferous outcrops across the world are ultramafic soils rich in nickel (Ni), chromium $(\mathrm{Cr})$, iron $(\mathrm{Fe})$, and magnesium $(\mathrm{Mg})$ (Harrison and Rajakaruna 2011), but natural outcrops rich in $\mathrm{Fe}$, manganese $(\mathrm{Mn})$, copper $(\mathrm{Cu})$, cobalt $(\mathrm{Co})$, and other rare minerals also occur. These metalliferous outcrops support unique vegetation adapted to high metal concentrations (i.e., $\mathrm{Ni}, \mathrm{Cr}, \mathrm{Fe}$, or $\mathrm{Mg}$ ) and, in general, nutrient deficiency and cation imbalances. Vegetation occurring in metal-rich habitats may present an important proportion of endemic species (Rajakaruna 2004; Faucon et al. 2010; Arnacker 2011). These endemics significantly contribute to the biodiversity of some regions of the world (Kruckeberg et al. 1985; Jacobi et al. 2007; Anacker et al. 2014; van der Ent et al. 2015b). For example, in California, endemic species from ultramafic rock outcrops represent close to $12 \%$ of the state endemic flora (Kruckeberg et al. 1990; Safford et al. 2005); in New Caledonia, they correspond to almost $60 \%$ of the island's indigenous flora (Jaffré 1992).

In addition, metallicolous flora represents a remarkable biological resource for eco-technological applications, especially phytoremediation of contaminated soils (Boisson et al. In press; Shutcha et al. 2010; Shutcha et al. 2015; van der Ent et al. 2015c). Whiting et al. (2004) considered these species an "El Dorado" of genetic material, which could be used for decontamination or ecological restoration of metal-contaminated sites. Implications in eco-technologies are particularly enhanced with the valorisation of metals in biomass from hyper-accumulators in green chemistry $(\mathrm{Zn}, \mathrm{Ni}$, Platinium - Pt, $\mathrm{Cu}, \mathrm{Co}$, and Manganese - $\mathrm{Mn})$ as catalysts in organic synthesis of molecules of interest (Losfeld et al. 2012; Escande et al. 2014; Grison 2014).

As metallicolous vegetation often occurs on economically valuable mineral deposits, many are threatened by quarrying and mining activities (Erskine et al. 2012; Faucon et al. 2011; Whiting et al. 2004). Moreover, 
extraction processes may lead to the contamination of adjacent nonmetalliferous habitats by industrial wastes (smelts, waste water, etc.), which might impact local plant diversity. Establishment of conservation and/or restoration programmes for plant biodiversity of metal-rich habitats (in-situ and ex-situ conservation) requires the understanding of relationships between soil and plant diversity. Knowledge of ecological and biogeochemical processes governing ecosystems, communities, and populations is fundamental to defining and applying ecological restoration of disturbed habitats (Palmer et al. 1997).

In southeastern DRC, natural copper and cobalt outcrops (Cu-Co outcrops) host remarkable herbaceous communities that comprise the so-called "copper flora". These outcrops form isolated and scattered hills in a landscape matrix of Miombo woodland (Duvigneaud and Denaeyer-De Smet 1963; Duvigneaud 1959; Fig. 1) (http://copperflora.org/eflora/). The Cu-Co outcrops present a variety of habitats according to a variation of edaphic conditions, including the natural $\mathrm{Cu}-\mathrm{Co}$ contamination level of the soil (Fig. 1). Mineralisation of the parent rocks and geological succession promotes the $\mathrm{Cu}$ and $\mathrm{Co}$ enrichment of the soils along the slope of the hills with concentrations of bioavailable $\mathrm{Cu}$ from 20 to $10,000 \mathrm{mg} \cdot \mathrm{kg}^{-1}$ and $\mathrm{Co}$ from 2 to $1,000 \mathrm{mg} \cdot \mathrm{kg}^{-1}$ toward the top of the $\mathrm{Cu}$ hills. These plant communities host more than 600 species tolerant to high $\mathrm{Co}$ and $\mathrm{Cu}$ concentrations (Leteinturier 2002). Among those tolerant species, 57 have been identified as endemic from the $\mathrm{Cu}-\mathrm{Co}$ outcrops (i.e., $\mathrm{Cu}-\mathrm{Co}$ endemics). The region, due to its extremely metal-rich subsoil, is currently at the forefront of mining activity. In DRC, $70 \%$ of metallophytes taxa (species or genera) are considered critically endangered (i.e., CR) and about 10\% would already have disappeared (Faucon et al. 2010; 2012a). In addition, southeastern DRC is one of the principal regions across the world presenting both environmental and public health issues associated with soil, air, and water contaminations resulting from an important $\mathrm{Cu}, \mathrm{Co}$, and uranium (U) extraction (Banza et al. 2009; Manda et al. 2010; Cheyns et al. 2014). There is an urgent need to develop conservation measures as well as restoration projects for the biodiversity of $\mathrm{Cu}$ and Co outcrops.

This paper reviews recent advances in our understanding of relationships between soil and plant diversity in metalliferous outcrops located in southeastern DRC and the implication of these recent advances in defining conservation and restoration strategies for the $\mathrm{Cu}-\mathrm{Co}$ ecosystems and their associated plant biodiversity. 
High $\mathrm{Cu}$ and $\mathrm{Co}$ concentrations in soil are phytotoxic and represent a strong selection pressure for plant species, which may induce ecological isolation and promote the speciation process (Duvigneaud and Denaeyer-De Smet 1963; Brooks and Malaisse 1990; Macnair and Gardner, 1998). Among the approximate 600 plant species of flora of $\mathrm{Cu}$-Co outcrops, 32 are strictly $\mathrm{Cu}$-Co endemic (i.e., absolute metallophyte occurring exclusively on $\mathrm{Cu}$ Co rich soils), and 23 are broad $\mathrm{Cu}-\mathrm{Co}$ endemics (i.e., facultative metallophyte with more than $75 \%$ of known populations occurring on $\mathrm{Cu}$-Co rich soils) (Faucon et al. 2010). At outcrop scale, $\mathrm{Cu}$ and Co concentrations are a primary determinant of the richness of plant species. Outcrops with the highest $\mathrm{Cu}$ and Co concentrations in soil support the lowest total plant species richness (Duvigneaud and Denaeyer-De Smet 1963; Saad et al. 2012; Séleck et al. 2013). This pattern is in contrast to the richness of endemic metallophyte, which rises with the increase of $\mathrm{Cu}$ and $\mathrm{Co}$ concentration in the soil (Saad et al. 2012; Séleck et al. 2013). At the landscape scale, the spatial configuration of $\mathrm{Cu}$-Co outcrops influences the richness of $\mathrm{Cu}$-Co endemics of species. In a recent study of $34 \mathrm{Cu}$-Co outcrops varying in size $(0.2$ ha to $27.3 \mathrm{ha})$ and geographical isolation in a $30 * 20 \mathrm{~km}$ landscape, Ilunga wa Ilunga et al. (unpublished results) demonstrated that $\mathrm{Cu}$-Co endemic richness is positively correlated to the site surface, which might be associated with higher habitat diversity. Using species accumulation curves, it was demonstrated that the three largest outcrops encapsulate the total $\mathrm{Cu}$-Co endemic richness ( 25 taxa) of the landscape, whereas at least 15 small $\mathrm{Cu}$-Co outcrops are necessary to reach the same endemic richness.

How does endemic metallophyte richness in southeastern DRC compare with other metallicolous floras? The proportion of strict metallophyte endemic in the copper flora, estimated at $5 \%$, is obviously low when compared with ultramafic floras of California, Cuba, and New Zealand but is rather similar to ultramafic floras of Italy or Great Dyke (Fig. 2). Endemic richness and the endemism percentage depend on a combination of different variables (Harrison et al. 2006). The history of geographical isolation is important to explain endemism patterns. Cuba and New Caledonia are oceanic islands with a long history of geographical isolation resulting in a high global level of endemism (Fig. 2). The age of exposure of metalliferous outcrops may also be an important factor to explain the proportion of endemics in a metallicolous flora (Harrison et al. 2004). Copper mineralisation in southeastern DRC dates from the late Cambrian period (about 620 myr, François 1973)), but Cu-Co rich rocks have been exposed to plant colonisation for a much shorter period. Recent data indicate $2-3$ myr as a likely age for $\mathrm{Cu}$-Co outcrops (De Putter et al. 2010). This is similar to the age of exposure of California ultramafic outcrops (Harrison et al. 2004). Vegetation modification due to palaeoclimate variation might also be relevant to 
explain the endemism level in metallicolous floras. During the Holocene, tropical Africa experienced dramatic climate fluctuations, including a dry-cool period about 18,000 cal yr BP (Van Zinderen et al. 1988, Vincens et al. 2005), with a deglacial period between 16,500 and 12,300 cal yr BP, including a retreat of montane elements at higher altitudes on the plateau under warmer conditions. This led to evolutionary divergences between populations isolated on the Cu-Co outcrops. These relatively recent divergences might explain the low percentage of endemic species observed in the copper flora. The close morphological resemblance between $\mathrm{Cu}$ Co endemic plant species and more widespread counterparts, such as Vigna dolomitica and V. reticulata (Maxted et al. 2004), Crotalaria peschiana and C. subcaespitosa (Polhill 1982), Acalypha cupricola, A. fuscescens, and A. dikuluwensis (Levin et al. 2007), and Silene burchellii and S. cobalticola (Malaisse 1983), suggests that the speciation processes may be ongoing in the southeastern DRC region. This also supports the hypothesis that most of $\mathrm{Cu}-\mathrm{Co}$ endemic species are neo-endemics (Malaisse 1983; Brooks et al 1985; 1990). This implies a recent divergence under intense ecological isolation (Macnair and Gardner 1998; Rajakaruna 2004). Another factor that may contribute to the low metallophyte endemism in southeastern DRC is the relatively low total surface of mineralised soils. Based on a typical site surface of a few tenths of a hectare, the total area of the $\mathrm{Cu}$ Co outcrops may not exceed $100 \mathrm{~km}^{2}$, which is a small surface compared to the thousands of $\mathrm{km}^{2}$ of ultramafic soil existing in California, Cuba, or New Caledonia (Harrison and Rajakaruna 2011). Eventually, ecological isolation and selective forces acting on populations occurring on $\mathrm{Cu}-\mathrm{Co}$ rich soils may be overestimated. Unlike ultramafic soils, $\mathrm{Cu}$-Co rich soils of southeastern DRC are relatively rich in nutrients $(\mathrm{P}, \mathrm{Ca}$, and $\mathrm{Mg}$ ) (Faucon et al. 2011; Séleck et al. 2013), and $\mathrm{Cu}$ soil toxicity might be mitigated by organic matter and other metals in oxidated forms (Lange et al. 2014; Pourret et al. 2015).

Even if metal-rich habitats are favourable environments for evolutionary divergence, the exceptionally high endemism occurring in such habitats remains intriguing (Kay et al. 2011). Intrinsic characteristics of metaltolerant taxa may be responsible for the limitation of their ecological niche. One hypothesis for high endemism in metal-rich habitats might be a low ability of metallophyte to colonise non-metalliferous habitats due to constitutive needs in metals (Tadros 1957; Kay et al. 2011). For some Cu-Co endemic taxa, it has been demonstrated that biomass and fitness increase with $\mathrm{Cu}$ concentration in soil (Chipeng et al. 2009). Metal tolerance may also represent an adaptive cost responsible for a disadvantage of metallophyte in nonmetalliferous soils (Wu 1990; Macnair et al. 2000) with a reduced competitive ability of metallophyte in nonmetalliferous habitats. Some studies support the hypothesis that the restricted distribution of metallophyte on 
metal-rich soils could be due to their low resistance to pathogens. Metal toxicity constitutes a strong selection pressure against pathogens and herbivores, limiting pathogen and herbivory pressures on metallophytes (Noret et al. 2005). As a result, metal tolerant taxa may also be characterised by a decrease in defence against herbivory and pathogens, which could limit their colonisation of non-metalliferous habitats (Faucon et al. 2012b; Kazakou et al. 2008). Very few data exist for $\mathrm{Cu}$ flora, but it has been shown that the $\mathrm{Cu}-\mathrm{Co}$ endemic Crepidorhopalon perennis is able to grow on substrate without $\mathrm{Cu}$ only in axenic conditions (i.e., without soil biota) (Faucon et al. 2012b). However, this hypothesis is still controversial because some species of bacteria and fungi are perfectly adapted to metal-rich soils (Wakelin et al. 2014; Stefanowicz et al. 2008).

As a result of the complex interactions among physiological, ecological, and evolutionary factors, the ecological niches of $\mathrm{Cu}-\mathrm{Co}$ endemic from southeastern DRC vary widely (Faucon et al. 2011; 2012a). Congeneric species may present highly distinct edaphic niches. Crepidorhopalon perennis (P.A. Duvigneaud) Eb. Fisch. (Linderniaceae), a $\mathrm{Cu}-\mathrm{Co}$ endemic, occurs on soils richer in $\mathrm{Cu}$ compared to its pseudo-metallophyte congener C. tenuis (S. Moore) Eb. Fisch. (Faucon et al. 2011; 2012b). Boisson et al. (unpublished results) recently demonstrated that among eight $\mathrm{Cu}-\mathrm{Co}$ endemic species present on the same $\mathrm{Cu}-\mathrm{Co}$ outcrops, five have their optimum niches in the lowest concentrations of $\mathrm{Cu}\left(<300 \mathrm{mg} \mathrm{Cu} \cdot \mathrm{kg}^{-1}\right)$ and $\mathrm{Co}\left(55 \mathrm{mg} \mathrm{Co.kg}{ }^{-1}\right)$ and only two have their optimum niches in the highest concentrations of $\mathrm{Cu}\left(>5,000 \mathrm{mg} \mathrm{Cu} \cdot \mathrm{kg}^{-1}\right)$. Species with their optimums in the higher $\mathrm{Cu} / \mathrm{Co}$ concentrations also present the largest $\mathrm{Cu} / \mathrm{Co}$ niche width. Ilunga wa Ilunga et al. (2013) found a similar pattern for non-endemic tolerant species on a Cu-Co outcrop in southeastern DRC. In addition, Ilunga wa Ilunga et al. (2013) demonstrated niche differentiation in relation to physical soil characteristics, namely rock cover and percentage of stones in the soil.

\section{Soil and Plant Communities' Co-variation.}

The physiognomy of vegetation varies on $\mathrm{Cu}-\mathrm{Co}$ outcrops from the top to the bottom along a topographical gradient corresponding roughly to the $\mathrm{Cu} / \mathrm{Co}$ gradient (Fig. 1). At the top, chasmophytic vegetation generally develops on poorly mineralised rocks (i.e., plant communities colonising the cracks and fissures of low mineralised rock with $\mathrm{Cu}$ concentrations of 250-900 $\mathrm{mg} \mathrm{kg}^{-1}$ ). Steppe vegetation colonises the upper part of the outcrops with the highest $\mathrm{Cu}$ soil concentrations (ranging from 3,500 to $10,000 \mathrm{mg} \mathrm{kg}^{-1}$ ). Finally, steppic savannah vegetation develops on the intermediate and foothill slopes and flat periodically flooded savannahs (dembos) at the bottom of the outcrops with $\mathrm{Cu}$ concentrations varying from 100 to 3,500 $\mathrm{mg} \mathrm{kg}^{-1}$ (Duvigneaud 
and Denaeyer-De Smet 1963; Brooks et al. 1985; Saad et al. 2012; Séleck et al. 2013) (Fig. 1). However, vegetation proved to be more complex than a simple succession of physiognomic plant formations along correlated $\mathrm{Cu}$ and $\mathrm{Co}$ gradients. More detailed studies revealed a mosaic of plant communities differing in species assemblages within and among Cu-Co outcrops (Saad et al. 2012; Séleck et al. 2013; Ilunga wa Ilunga et al. 2013).

Although (extractable) $\mathrm{Cu}$ and $\mathrm{Co}$ soil concentrations are the main factors correlated to variation in species composition among plant communities on $\mathrm{Cu}$-Co outcrops, the mosaic of plant communities is also related to complex variations of other inter-correlated chemical factors. For example, in addition to differences in $\mathrm{Cu}-\mathrm{Co}$ concentrations, steppic communities present higher values for $\mathrm{pH}, \mathrm{C}, \mathrm{N}$, and extractable $\mathrm{Ca}$ and $\mathrm{P}$ (acetateEDTA) and lower values for the C:N ratio and extractable Fe and $\mathrm{K}$ concentrations compared to steppic savannah communities. Besides the potential direct effect on species assemblages, soil factors, such as $\mathrm{pH}, \mathrm{C}, \mathrm{Ca}$ and $\mathrm{Mn}$, can also contribute indirectly to floristic variation and heterogeneity of plant communities in $\mathrm{Cu}$ outcrops (Saad et al. 2012; Ilunga wa Ilunga et al. 2013; Séleck et al. 2013) because they can influence Cu and Co availability and toxicity (Lange et al. 2014; Pourret et al. 2015). Cobalt has a high affinity for manganese oxides (MnOx). A higher $\mathrm{MnOx}$ concentration in soil can decrease Co availability and toxicity (Collins et al. 2011). In the same way, high concentrations of iron oxides and organic matter in soils can reduce $\mathrm{Cu}$ availability (Kabala et al. 2001). Characterisation of metal speciation in soils also suggests a strong relationship between $\mathrm{Cu}$ and Co speciation in soils and structures of plant communities on a single Cu-Co outcrop (Fig. 3). A steppe community (Community 3 in Fig. 3) is associated with high concentrations of $\mathrm{Cu}$ and $\mathrm{Co}$ fractions that are considered available (i.e., $\mathrm{Cu}-\mathrm{Free}, \mathrm{Cu}-\mathrm{FeOx}$ (Cu-iron oxides), $\mathrm{Cu}-\mathrm{MnOx}$, Co-Free, and $\mathrm{Co}-\mathrm{FeOx}$ ) (Lange et al. 2014). A second steppe community (Community 2 in Fig. 3) presents the highest concentrations of unavailable $\mathrm{Cu}$ and $\mathrm{Co}$ fractions (i.e., $\mathrm{Cu}-\mathrm{OM}$ and $\mathrm{Co}-\mathrm{MnOx}$ ) and less $\mathrm{Cu}-\mathrm{Co}$-tolerant species. Variation of $\mathrm{Cu}$ and $\mathrm{Co}$ chemical forms in soils may create spatial heterogeneity of soil properties that promotes a diversity of plant assemblages (Fig. 4). It may be hypothesised that the diversity of $\mathrm{Cu}$ and Co chemical forms in soil decreases metal availability and toxicity and promotes plant species diversity.

Nutrient content does not seem restrictive for the vegetation of $\mathrm{Cu}-\mathrm{Co}$ outcrops; the amount of the essential macronutrients is higher on $\mathrm{Cu}$-Co outcrops than on non-metalliferous soils in southeastern DRC (Saad et al. 2012; Séleck et al. 2013). This differs from ultramafic soils where deficiencies in N, P, K, and Ca have been suggested as a potential reason for limited plant productivity (O’Dell et al. 2006; Whittaker 1954). It can be thus 
inferred that selection pressure may be more strongly influenced by metal toxicity than by a high variation of nutrient content. However, the covariation of plant communities with nutrients, partly independent from metal availability (Seleck et al. 2013), suggests the need for a deeper exploration of the effect of $\mathrm{N}$ and P through the examination of the variation of the foliar N:P ratio and experimentation on $\mathrm{P}$ limitations along a $\mathrm{Cu} / \mathrm{Co}$ gradient, where both the diversity and productivity of plant species should be measured (Aerts and Chapin 1999).

Variations of $\mathrm{Cu}$ and $\mathrm{Co}$ concentrations in soil also involve variations in trait responses of plant species. Delhaye et al. (unpublished results) showed that the gradient of soil metal concentrations is associated with a pattern of trait substitution rather than high intraspecific trait variation. At the community-level, trait variation results in a shift in the abundances of various life forms. Xylopod species (i.e., with underground storage organs) are dominant in the lower part of the $\mathrm{Cu}-\mathrm{Co}$ outcrops in communities occurring on deeper soils that are less rich in metal, whereas annual species are dominant in the upper part of the $\mathrm{Cu}$-Co outcrop in communities located on more shallow soils with high metal concentrations (Séleck et al. 2013).

Implication of Plant-soil Relationships for Conservation and Restoration of Plant Biodiversity in Cu-Co Outcrops in Southeastern DRC

The first strategy from a biodiversity conservation point of view would include the preservation of a proportion of $\mathrm{Co}-\mathrm{Cu}$ outcrops in protected areas. As demonstrated by endemism patterns at the landscape scale, the preservation of a limited number of $\mathrm{Cu}$-Co outcrops occurring in southeastern DRC should allow the conservation of a set of populations of most $\mathrm{Cu}-\mathrm{Co}$ endemic species. In contrast, the preservation of the diversity of plant communities in untouched protected $\mathrm{Cu}$-Co outcrops will be far more challenging. The high diversity of plant communities as well as the variability of plant assemblages among outcrops would need to preserve a large proportion of $\mathrm{Cu}-\mathrm{Co}$ outcrops if ecosystem diversity must be addressed. This may turn out to be a limited and economically unrealistic option, considering the increasing demand for $\mathrm{Cu}$ and $\mathrm{Co}$ in the world and the high contribution of the $\mathrm{Cu}-\mathrm{Co}$ market to the economy of the DRC.

A valuable alternative to preserving the extraordinary biological heritage of $\mathrm{Cu}$-Co outcrops is to set up, prior to ecological restoration and rehabilitation of sites at mine closure, an ex-situ conservation strategy at the level of plant communities with topsoil and community translocation and at the level of individual species with translocation of individuals in restored habitats, conservation and multiplication in botanical gardens, and long 
term ex-situ seed banks for most characteristic species (http: //www.copperflora. org: Conservation; Godefroid et al. 2013) (Fig. 5).

In this review, we have highlighted that extractable $\mathrm{Cu}$-Co soil concentrations and other edaphic soil factors (i.e., $\mathrm{pH}, \mathrm{C}, \mathrm{N}, \mathrm{Ca}, \mathrm{Mn}$, and $\mathrm{Fe}$ ) are the main drivers structuring plant communities, and their variation is partly responsible for the heterogeneity of communities observed at the scale of the $\mathrm{Cu}$-Co outcrops. Alteration and/or modifications of edaphic conditions of $\mathrm{Cu}-\mathrm{Co}$ outcrops therefore have important consequences on vegetation composition and structure. Plant communities of $\mathrm{Cu}-\mathrm{Co}$ outcrops are poorly or not resilient to strong anthropogenic disturbances, such as mineral extraction, made either by artisanal miners or mining companies (Ilunga wa Ilunga et al. 2015). The comparison, in terms of species composition and/or abundance of functional traits, between primary plant communities occurring on $\mathrm{Cu}$-Co outcrops and secondary plant communities resulting from the re-colonisation of disturbed areas (i.e., altered areas after mineral extraction with potentially deposition of mining waste) did not show any functional resilience of the primary communities, even after 30 years of degradation by mining (Faucon et al. 2011; Ilunga wa Ilunga et al. 2015). Conservation or restoration of the soil factors is therefore necessary and crucial to conserve plant community on $\mathrm{Cu}-\mathrm{Co}$ outcrops. southeastern DRC by Tenke Fungurume Mining, a mining company (Fig. 5). The initial results of these translocations demonstrate that vegetation mat translocation is the most efficient method to preserve the biodiversity of $\mathrm{Cu}$-Co outcrops compared to topsoil transfer (Le Stradic et al. In press). In contrast to topsoil transfer, vegetation mat translocation allows transference of numerous species with fewer non-target species, probably due to a higher competition with the already established vegetation. For steppic savannahs, the seed bank is poor in species and seeds, and little emergence of target species (i.e., copper flora species) occurs in the topsoil, while ruderal species quickly colonise bare ground areas. Results are more encouraging for the steppe, given that high metal concentrations (i.e., $\mathrm{Cu}$ and $\mathrm{Co}$ ) appear to limit the development of ruderal species, and a greater number of annual species provides a more rapid vegetation cover from the first year with some target species of copper flora (i.e., species present in the pristine $\mathrm{Cu}$-Co communities), such as Bulbostylis cupricola Goetgh. or Haumaniastrum robertii (Robyns) P.A. Duvign. and Plancke. Steppic communities present shallow soils, favouring the transfer of the plant community without root damage. In contrast, vegetation mat translocation failed to transfer structuring xylopod species (i.e., dominant species) with important underground systems, such as Cryptosepalum maraviense (Fabaceae). The absence of xylopods in translocated ecosystems 
may modify underground competition relationships within the community and promote the dominance of Poaceae species. While edaphic conditions are essential in order to restore $\mathrm{Cu}-\mathrm{Co}$ communities properly, biotic filters and species interactions are also necessary to structure plant communities occurring on $\mathrm{Cu}$-Co outcrops, and more research on this topic is necessary.

Ex-situ conservation of individual species also introduces great challenges. In this review, we have highlighted interspecific variations in realised ecological niches of $\mathrm{Cu}-\mathrm{Co}$ endemics in relation to $\mathrm{Cu}$ and $\mathrm{Co}$ concentrations in soils but also other chemical and physical soil factors. This suggests that conservation strategies need to be species-specific and cannot be generalisable for all endemic metallophytes, particularly if the aim of the ex-situ conservation strategy is reintroducing and self-sustaining populations in restored habitats. In the short term, detailed studies are needed to characterise both the fundamental and realised niches of endemic metallophytes from $\mathrm{Cu}-\mathrm{Co}$ outcrops (Schenk 2008). Characterisation of the fundamental niches of $\mathrm{Cu}-\mathrm{Co}$ endemics (i.e., the physiological tolerance of a species in the absence of biotic interactions) will be crucial to developing ex-situ conservation and multiplication programmes in botanical gardens before reintroduction in restored habitats.

Although species conservation priorities are generally based on rarity and species extinction threats (IUCN criteria), conservation strategies for $\mathrm{Cu}$-Co metallophytes should also integrate the conservation of genetic diversity within the region. Some genetic variation of adaptive traits exists between populations of the same species. Genetic variation between populations of $\mathrm{Cu}$ tolerance and accumulation has been demonstrated in two pseudo-metallophytes, Crepidorhopalon tenuis and Haumaniastrum katangense (Faucon et al. 2012b; Peng et al. 2012). This genetic variability of $\mathrm{Cu}$ tolerance and accumulation is an opportunity to select the most tolerant populations and define phytoremediation processes (phytoextraction or phytostabilisation).

\section{Conclusion}

290 This review highlights advances in knowledge of plant diversity of natural $\mathrm{Cu}$-Co outcrops at different scales or ecological levels (flora, ecosystems, plant species communities, and plant populations) in order to provide guidelines and identify knowledge gaps to define biodiversity conservation programmes. In mining regions where there is an obvious conflict of interest between economically important mining activities and conservation of plant biodiversity of natural metalliferous outcrops, there is an urgent need to define science-based strategies for biodiversity conservation, including in-situ and ex-situ approaches, ecosystem reconstruction, and postmining restoration (Fig 5). Ex-situ conservation prior to mining activities could be undertaken on available areas 
adjacent to mineralised outcrops with $\mathrm{Cu}-\mathrm{Co}$ rich soils or $\mathrm{Cu}-\mathrm{Co}$ enriched soils. Plant diversity, especially metallophytes, even in ex-situ conservation areas, is a genuine resource for phytoremediation of degraded postmining areas. Future challenges are to conciliate biodiversity conservation and ecological engineering for phytoremediation of $\mathrm{Cu}-\mathrm{Co}$ contaminated soils generated by mining activities. This goal will be reached only if a strong cooperation between scientists, field conservationists, and mining companies is set up. Considering the urgency of the situation, scientific studies should be a full part of conservation strategies. In turn, learning from true conservation experience needs to be designed now (research by design) and will be a key method for increasing our scientific knowledge of this exceptional biological resource.

\section{Acknowledgments}

The authors are grateful to Hans Lambers and Etienne Laliberté (School of Plant Biology, University of Western Australia) and Antony van der Ent (Centre for Mined Land Rehabilitation, University of Queensland) for relevant comments and language revision of the manuscript. University of Lubumbashi and the NGO Biodiversité au southeast DRC (BAK) are gratefully acknowledged for the welcome given to MPF. We thank the company Tenke Fungurume Mining (TFM) for the logistic and financial support to conduct part of our study and the Fonds de la Recherche dans l'Industrie et dans l'Agriculture (FRIA) of the FNRS (Fonds National de la Recherche Scientifique), Belgium for their financial support.

\section{References}

Aerts R, Chapin FS (1999) The mineral nutrition of wild plants revisited: a re-evaluation of processes and patterns. Adv. Ecol. Res. 30:1-67

Anacker BL (2011) Phylogenetic Patterns of Endemism and Diversity. In: Harrison, S.P., Rajakaruna, N. eds. Serpentine: The Evolution and Ecology of a Model System. University of California Press, Berkeley, 49-79.

Anacker BL, Klironomos JN, Maherali H, Reinhart KO, Sharon YS (2014) Phylogenetic conservatism in plantsoil feedback and its implications for plant abundance. Ecol. Lett. 1613-1621

Baker A, Brooks R, Pease A, Malaisse F (1983) Studies on copper and cobalt tolerance in three closely related taxa within the genus Silene L.(Caryophyllaceae) from Zaïre. Plant Soil 385:377-385 
Banza CLN, Nawrot TS, Haufroid V, Decrée S, De Putter T, Smolders E, Kabyla BI, Luboya ON, Ilunga AN,

324 Mutombo AM, Nemery B (2009) High human exposure to cobalt and other metals in South-East DRC, a mining area of the Democratic Republic of Congo. Environ. Res. 109:745-52

Boisson S, Le Stradic S, Collignon J, Malaisse F, Shutcha MN, Faucon M-P, Mahy G (2015) Potential of copper-tolerant grasses to implement phytostabilisation strategies on polluted soils in South D. R. Congo. Environ Sci Pollut Res. In press. doi: 10.1007/s11356-015-5442-2

Brady KU, Kruckeberg AR, Bradshaw JHD (2005) Evolutionary Ecology of Plant Adaptation To Serpentine Soils. Annu. Rev. Ecol. Evol. Syst. 36:243-266

Brooks RR (1987) Serpentine and its vegetation: a multidisciplinary approach, Ecology, phytogeography \& physiology series. Dioscorides Press, Portland, OR

Brooks RR, Malaisse F (1985) The Heavy Metal Tolerant Flora of Southcentral Africa: a mutlidisciplinary approach. A.A. Balkema, Rotterdam.

Brooks RR, Malaisse F (1990) Metal-enriched sites in south central africa. In: Shaw, J. ed. Heavy Metal Tolerance in Plants: Evolutionary Aspects. CRC Press, Inc, New York, 53-71.

Borhidi A (1996) Phytogeography and vegetation ecology of Cuba.

Cheyns K, Banza Lubaba Nkulu C, Ngombe LK, Asosa JN, Haufroid V, De Putter T, Nawrot T, Kimpanga CM, Numbi OL, Ilunga BK, Nemery B, Smolders E (2014) Pathways of human exposure to cobalt in South-East DRC, a mining area of the DR Congo. Sci. Total Environ. 490:313-321

Chipeng FK, Hermans C, Colinet G, Faucon M-P, Ngongo M, Meerts P, Verbruggen N (2009) Copper tolerance in the cuprophyte Haumaniastrum katangense (S. Moore) P.A. Duvign. \& Plancke. Plant Soil 328:235-244

Collins RN, Kinsela AS (2011) Pedogenic factors and measurements of the plant uptake of cobalt. Plant Soil 339:499-512

Cowling RM, Lombard AT (2002) Heterogeneity, speciation/extinction history and climate: explaining regional plant diversity patterns in the Cape Floristic Region. Divers. Distrib. 8:163-179 
De Putter T, Mees F, Decrée S, Dewaele S (2010) Malachite, an indicator of major Pliocene Cu remobilization in a karstic environment (South-East DRC, Democratic Republic of Congo). Ore Geol. Rev. 38:90-100 Duvigneaud P (1959) Plantes cobaltophytes dans le Haut South-East DRC. Bull. la Société R. Bot. Belgique 91:111-134 Duvigneaud P, Denaeyer-De Smet S (1963) Cuivre et végétation au South-East DRC. Bull. la Société R. Bot. Belgique. 96:93-224

Erskine P, Van der Ent A, Fletcher A (2012) Sustaining metal-loving plants in mining regions. Science $337: 1172-1173$

Escande V, Olszewski T, Grison C (2014) From biodiversity to catalytic diversity: how to control the reaction mechanism by the nature of metallophytes. Environ. Sci. Pollut. Res.:1-14

Escudero A, Palacio S, Maestre FT, Luzuriaga AL (2015) Plant life on gypsum: a review of its multiple facets. Biol. Rev. 90:1-18

Faucon M-P, Tshilong BM, Van Rossum F, Meerts P, Decocq G, Mahy G (2012a) Ecology and Hybridization Potential of Two Sympatric Metallophytes, the Narrow Endemic Crepidorhopalon perennis ( Linderniaceae ) and its More Widespread Congener. Biotropica 44:454-462

362 Faucon M.-P, Chipeng F, Verbruggen N, Mahy G, Colinet G, Shutcha M, Pourret O, Meerts P (2012b) Copper tolerance and accumulation in two cuprophytes of South Central Africa: Crepidorhopalon perennis and C. tenuis (Linderniaceae). Environ. Exp. Bot. 84:11-16 Faucon M.-P, Colinet G, Mahy G, Ngongo Luhembwe M, Verbruggen N, Meerts P (2009) Soil influence on Cu and Co uptake and plant size in the cuprophytes Crepidorhopalon perennis and C. tenuis (Scrophulariaceae) in SC Africa. Plant Soil 317:201-212 endemism in the Congolese flora: a database of copper affinity and conservational value of cuprophytes. Plant Ecol. Evol. 143:5-18 
Metallophytes Benefit from Disturbed Soils Following Mining Activity? The Case of the Crepidorhopalon tenuis in South-East DRC (D. R. Congo). Restor. Ecol. 19:333-343

François A., 1973. L'extrémité occidentale de l'Arc Cuprifère Shabien. Etude géologique-Département de géologie de la Gécamines, Likasi (République du Zaire).

Godefroid S, Van de Vyver A, Massengo Kalenga W, Handjila Minengo G, Rose C, Ngongo Luhembwe M, from the South-East DRC copper belt (DR Congo): implications for ex situ conservation. Plant Ecol. Evol.

Grison C (2014) Combining phytoextraction and ecocatalysis: a novel concept for greener chemistry, an opportunity for remediation. Environ. Sci. Pollut. Res. 1-3

Harrison S, Safford HD, Grace JB, Viers JH, Davies KF (2006) Regional and local species richness in an insular environment: serpentine plants in California. Ecol. Monogr. 76:41-56

Hayes P, Turner BL, Lambers H, Laliberté E (2014) Foliar nutrient concentrations and resorption efficiency in plants of contrasting nutrient-acquisition strategies along a 2-million-year dune chronosequence. $\mathrm{J}$ of ecology 102:396-410.

Hopper SD, Gioia P (2004) The southwest Australian floristic region: evolution and conservation of a global hot spot of biodiversity. Annu. Rev. Ecol. Evol. Syst. 623-650 and distribution of species niches on a copper rock outcrop in Upper South-East DRC, DR Congo. Plant Ecol. 

traits as a promising approach for the ecological restoration of degraded tropical metal-rich habitats and revegetation of metal-rich bare soils. Ecol. Eng. 82: 214-221

Jacobi CM, Do Carmo FF, Vincent RC, Stehmann JR (2007) Plant communities on ironstone outcrops: a diverse and endangered Brazilian ecosystem. Biod. Cons. 16: 2185-2200

Kabala C, Singh BR (2001) Fractionation and mobility of copper, lead, and zinc in soil profiles in the vicinity of a copper smelter. J. Environ. Qual. 30:485-492

Kay KM, Ward KL, Watt LR, Schemske DW (2011) Plant speciation. Serpentine: the evolution and ecology of a model system, 71-96

Kazakou E, Dimitrakopoulos PG, Baker AJM, Reeves RD, Troumbis AY (2008) Hypotheses, mechanisms and trade-offs of tolerance and adaptation to serpentine soils: From species to ecosystem level. Biol. Rev. 83:495508 Kruckeberg AR, Rabinowitz D (1985) Biological Aspects of Endemism in Higher Plants. Annu. Rev. Ecol. Syst. $16: 447-479$

Kruckeberg AR, Kruckeberg A (1990) Endemic metallophytes: their taxonomic, genetic and evolutionary attributes. In: Shaw, J. ed. Heavy Metal Tolerance in Plants: Evolutionary Aspects. CRC Press Inc, New York, $301-312$

Küper W, Sommer JH, Lovett JC, Mutke J, Linder HP, Beentje HJ, Sylva R, Van Rompaey A-R, Chatelain C, Sosef M, Barthlott W (2004) Africa's hotspots of biodiversity redefined. Ann. Mo. Bot. Gard. 525-535 does pedogenesis drive plant diversity? Trends Ecol. Evol. 28:331-340

417 Lambers H, ed (2014) Plant Life on the Sandplains in Southwest Australia, a Global Biodiversity Hotspot. University of Western Australia Publishing, Crawley, Australia. 
Lambers H, Brundrett MC, Raven JA, Hopper SD (2010) Plant mineral nutrition in ancient landscapes: high plant species diversity on infertile soils is linked to functional diversity for nutritional strategies. Plant Soil $334: 11-31$

Lange B, Faucon M-P, Meerts P, Shutcha M, Mahy G, Pourret O (2014) Prediction of the edaphic factors influence upon the copper and cobalt accumulation in two metallophytes using copper and cobalt speciation in soils. Plant Soil 379:275-287

Le Stradic S, Séleck M, Lebrun J, Boisson S, Handjila G, Faucon MP, Mahy G (2016) Comparison of translocation methods to conserve metallophyte communities in the Katangan copperbelt, DRC. Environ. Sci. Pollut. Res. In press

Levin GA, Morton JK, Robbrecht E (2007) Two New Species of <I>Acalypha</I > (Euphorbiaceae) from Tropical Africa, and a Review of Some Robyns Names for Cupricolous Plants From the Democratic Republic of the Congo. Syst. Bot. 32:576-582

Leteinturier B (2002) Evaluation du potential phytocénotique des gisements cuprifères d'Afrique centro-australe en vue de la phytoremédiation de sites pollués par l'activité minière. PhD. Thesis, Faculté des Sciences agronomiques de Gembloux, Belgium

Losfeld G, Escande V, Jaffré T, L’Huillier L, Grison C (2012) The chemical exploitation of nickel phytoextraction: an environmental, ecologic and economic opportunity for New Caledonia. Chemosphere 89:907-10

Macnair M, Gardner M (1998) The Evolution of Edaphic Endemics. In: Howard, D., Berlocher, S. eds. Endless Forms. Species and Speciation. Oxford University Press, New York, 157-171

Malaisse F (1983) Phytogeography of the copper and cobalt flora of Upper Shaba (Zaïre), with emphasis on its endemism, origin and evolution mechanisms. Bothalia 14:497-504

Manda B, Colinet G, André L (2010) Evaluation de la contamination de la chaîne trophique par les éléments traces $(\mathrm{Cu}, \mathrm{Co}, \mathrm{Zn}, \mathrm{Pb}, \mathrm{Cd}, \mathrm{U}, \mathrm{V}$ et As) dans le bassin de la Lufira supérieure (South-East DRC). Tropicultura 246-252 
Maxted N, Mabuza Dlamini P, Moss H, Padulosi S, Jarvis A, Guarino L (2004) An ecogeographic study: African Vigna

Noret N, Meerts P, Tolrà R, Poschenrieder C, Barceló J, Escarre J (2005) Palatability of Thlaspi caerulescens for snails: influence of zinc and glucosinolates. New Phytol. 165:763-71

O'Dell RE, James JJ, Richards JH (2006) Congeneric serpentine and nonserpentine shrubs differ more in leaf Wagner H., 2011. Package "vegan ."

452 Palmer MA, Ambrose RF, Poff NLR (1997) Ecological theory and community restoration ecology. Restor. Ecol. $5: 291-300$

Peng H, Wang-Müller Q, Witt T, Malaisse F, Küpper H (2012) Differences in copper accumulation and copper stress between eight populations of Haumaniastrum katangense. Environ. Exp. Bot. 79:58-65

Polhill RM (1982) Crotalaria in Africa and Madagascar. Taylor \& Francis.

Pourret O, Lange B, Houben D, Colinet G, Shutcha M, Faucon M-P (2015) Modeling of cobalt and copper 460 speciation in metalliferous soils from South-East DRC (Democratic Republic of Congo). J. Geochemical Explor. 149:87-96 Essential Step in a Biodiversity Conservation Plan. Restor. Ecol. 20:405-415 affinity. Madroño 52:222-257 

soil factors influencing plant assemblages along copper-cobalt gradients: implications for conservation and restoration. Plant Soil 373:455-469

472 Shutcha M, Faucon MP, Kamengwa Kissi C, Colinet G, Mahy G, Ngongo Luhembwe M., Visser M, Meerts P. 473 (2015) Three years of phytostabilisation experiment of bare acidic soil extremely contaminated by copper 474 smelting using plant biodiversity of metal-rich soils in tropical Africa (South-East DRC, DR Congo). Ecol. Eng. 82: $81-90$ Phytostabilisation of copper-contaminated soil in South-East DRC: an experiment with three native grasses and two amendments. Int. J. Phytoremediat. 12:616-632 Silveira FA, Negreiros D, Barbosa NP, Buisson E, Carmo FF, Carstensen DW, Conceição AA, Cornelissen TG, 480 Echternacht L, Fernandes GW, Garcia QS, Guerra TJ, Jacobi CM, Lemos-Filho JP, Le Stradic S, Morellato LPC, Neves FS, Oliveira RS, Schaefer CE, Viana PL, Lambers H (2015) Ecology and evolution of plant diversity in the endangered campo rupestre: a neglected conservation priority. Plant Soil:1-24 Stefanowicz AM, Niklińska M, Laskowski R (2008) Metals affect soil bacterial and fungal functional diversity differently. Environ. Toxicol. Chem. 27:591-598 Tadros TTM (1957) Evidence of the presence of an edapho-biotic factor in the problem of serpentine tolerance. Ecology 38:14-23 Jacobi CM, Carmo FF, Vincent RC, Stehmann JR (2007) Plant communities on ironstone outcrops: a diverse and endangered Brazilian ecosystem. Biodivers. Conserv. 16:2185-2200 (Malaysia). Aust. J. Bot. Australia-Pacific Region: state of knowledge and research priorities. Aust. J. Bot. 
van der Ent A, Baker AJM, Reeves RD, Chaney RL, Anderson CWN, Meech JA, Erskine PD, Simonnot M-O, Vaughan J, Morel JL, Echevarria G, Fogliani B, Rongliang Q, Mulligan DR (2015c) Agromining: farming for metals in the future? Environ. Sci. Technol. 49:4773-4780

Van Zinderen Bakker EM, Coetzee JA (1988) A review of late quaternary pollen studies in East, Central and Southern Africa. Rev. Palaeobot. Palynol. 55:155-174

Vincens A, Buchet G, Williamson D, Taieb M (2005) A 23,000 yr pollen record from Lake Rukwa $\left(8^{\circ} \mathrm{S}, \mathrm{SW}\right.$ Tanzania): New data on vegetation dynamics and climate in Central Eastern Africa. Rev. Palaeobot. Palynol. $137: 147-162$

Wakelin S, Gerard E, Black A, Hamonts K, Condron L, Yuan T, van Nostrand J, Zhou J, O'Callaghan M (2014) Mechanisms of pollution induced community tolerance in a soil microbial community exposed to $\mathrm{Cu}$. Environ. Poll. 190:1-9

Whittaker RH (1954) The Ecology of Serpentine Soils. Ecology 35:258-288

Whittaker RJ, Willis KJ, Field R (2001) Scale and species richness: towards a general, hierarchical theory of species diversity. J. Biogeogr. 28:453-470

Whiting SN, Reeves RD, Richards D, Johnson MS, Cooke JA, Malaisse F, Johns R, Mcintyre T, Purvis OW, Salt DE, Schat H, Zhao FJ, Baker AJM (2004) Research Priorities for Conservation of Metallophyte Biodiversity and their Potential for Restoration and Site Remediation. Restor. Ecol. 12:106-116

Wu L (1990) Colonisation and establishment of plants in contaminated sites. In: Heavy Metal Tolerance in Plants: Evolutionary Aspects (ed. A. J.Shaw), pp. 269-284. CRC Press, Boca Raton, FL. 


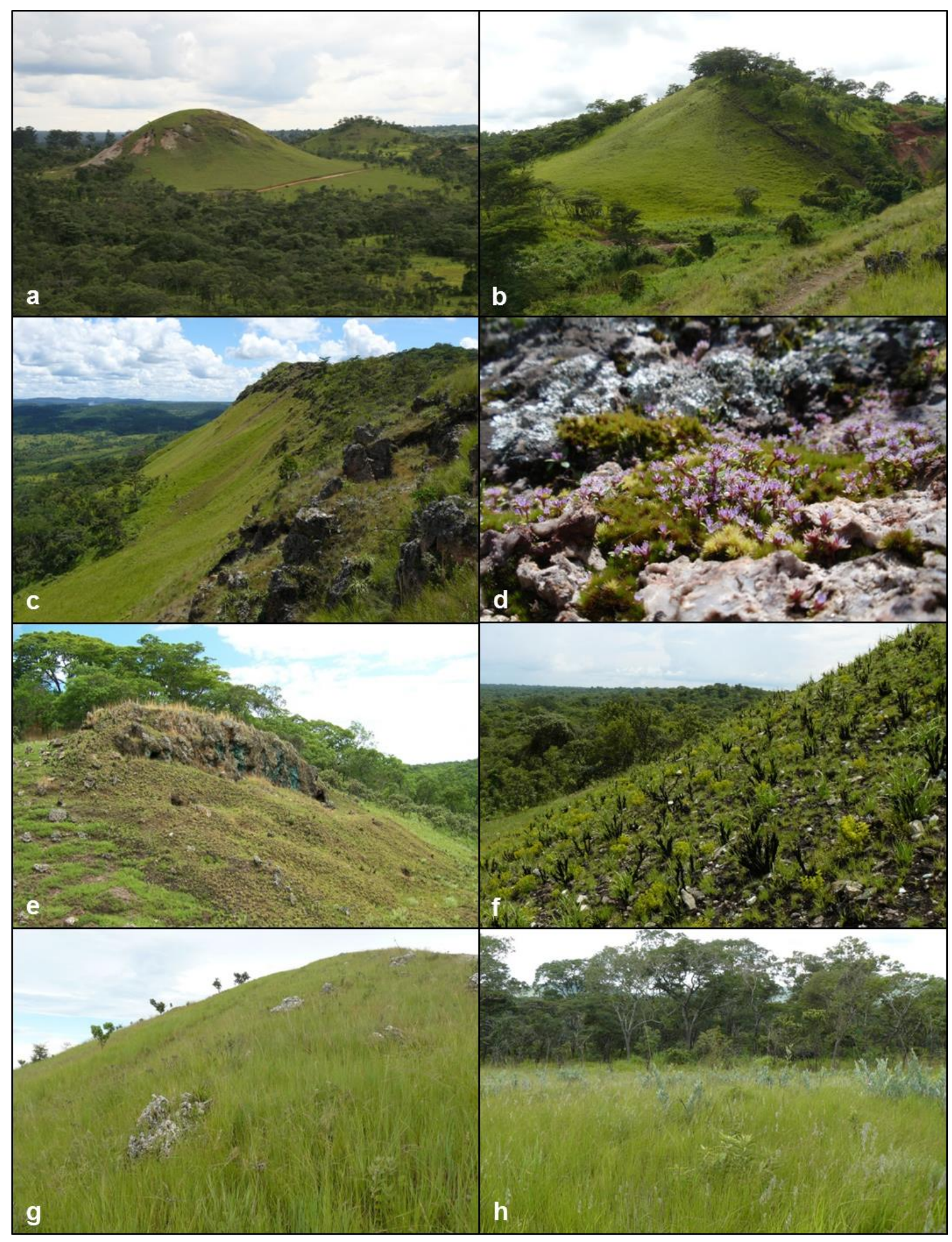


520 Fig. 1 a) b) and c) General overview of copper and cobalt outcrops in Southeastern DRC (Democratic Republic 521 of Congo), geographically isolated in the landscape matrix dominated by Miombo woodland on non-

522 metalliferous soils; d) chasmophytic vegetation at the top of $\mathrm{Cu}$-Co outcrops; e) et f) steppes on soils with high $523 \mathrm{Cu}-\mathrm{Co}$ content; g) steppic savannah on the slope and h) steppic savannah on downslope with lower $\mathrm{Cu}-\mathrm{Co}$ 524 content.

525 


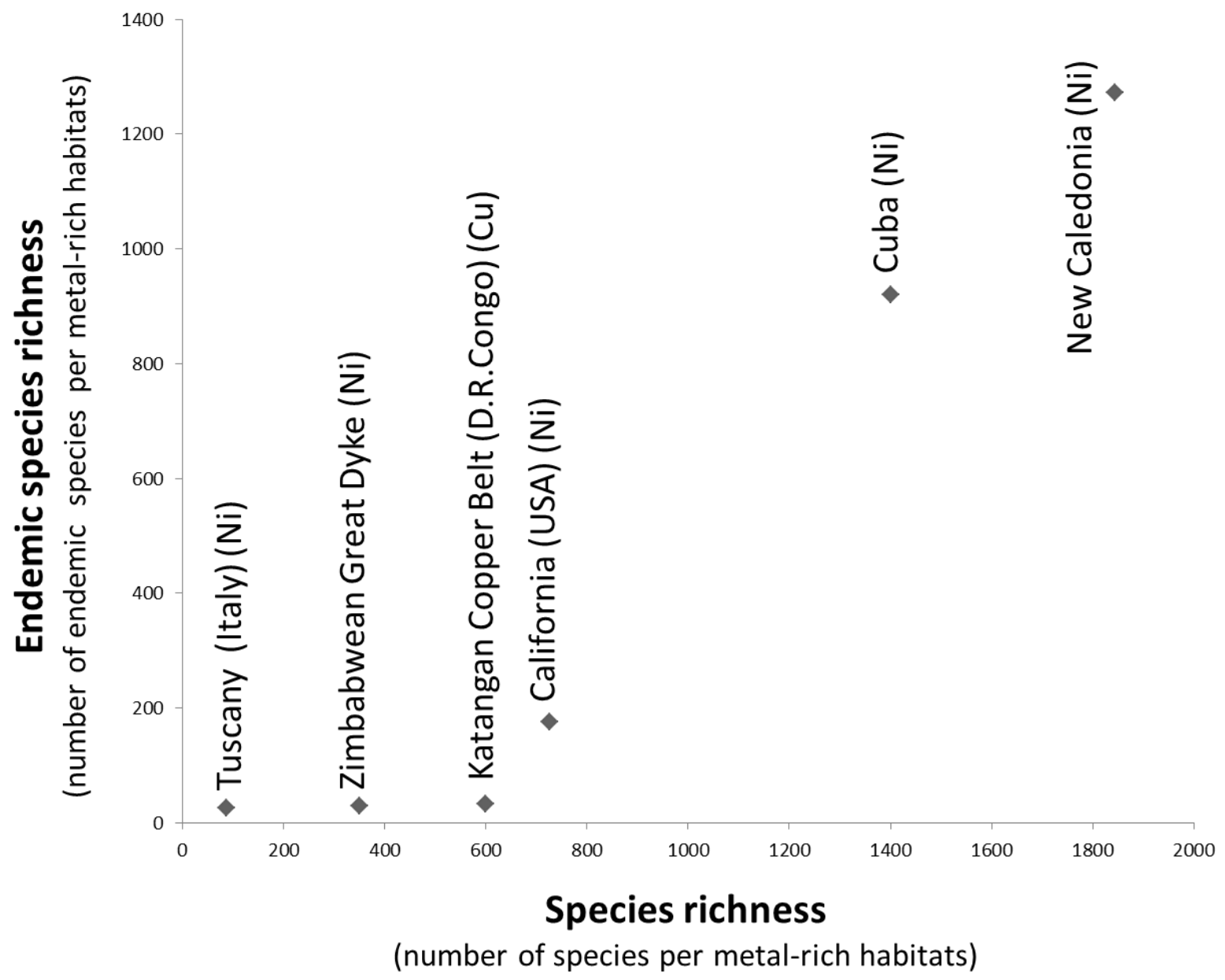

527 Fig. 2 Relationship between total plant species richness and metallophyte endemic richness on natural metal rich 528 soils in six metal world regions. Data are from Faucon et al. 2010; Wild 1965; Jaffré 1992; Borhidi 1996; 529 Kruckeberg 1984; Selvi 2007. 


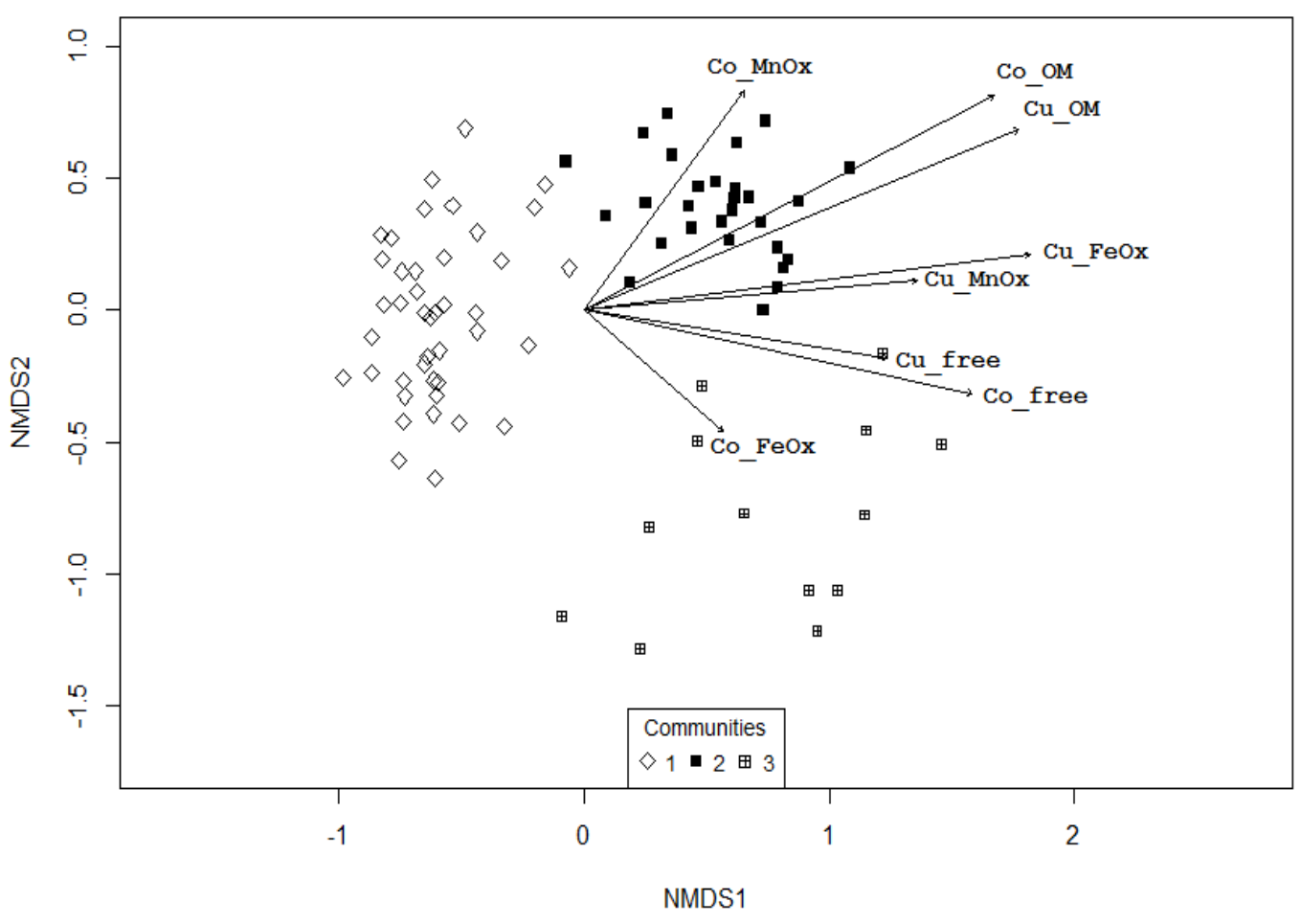

NMDS1

532 Fig. 3 NonMetrical Multidimensional scaling (NMDS) ordination diagram of plots ( $\mathrm{n}=83$ ) distributed in three 533 different communities on a $\mathrm{Cu}$-Co outcrop called Fungurume V. Fitted copper and cobalt fractions vectors are 534 overlain by using the envfit command of vegan package ( $\mathrm{R}$ statistical software, Oksanen et al. 2011). MnOx: 535 manganese oxides. FeOx: iron oxides. Community 1: Steppic savannah with Cryptosepalum maraviense 536 (Caesalpiniaceae); Loudetia simplex (Poaceae) et Scleria bulbifera (Cyperaceae) (Figure $1 \mathrm{photo} g$ and h).

537 Community 2: Steppe with Hyparrhenia diplandra (Poaceae); Schizachyrium brevifolium (Poaceae); Justicia 538 elegantula (Acanthaceae), Michrochloa altera (Poaceae); Xerophyta equisetoides (Velloziaceae) and Bulbostylis 539 cupricola (Cyperaceae) (Figure 1 photo f). Community 3: Steppe with Pandiaka carsonii (Amaranthaceae); 540 Ascolepis metallorum (Cyperaceae); Anisopappus davyi (Asteraceae) (Fig. 1). 


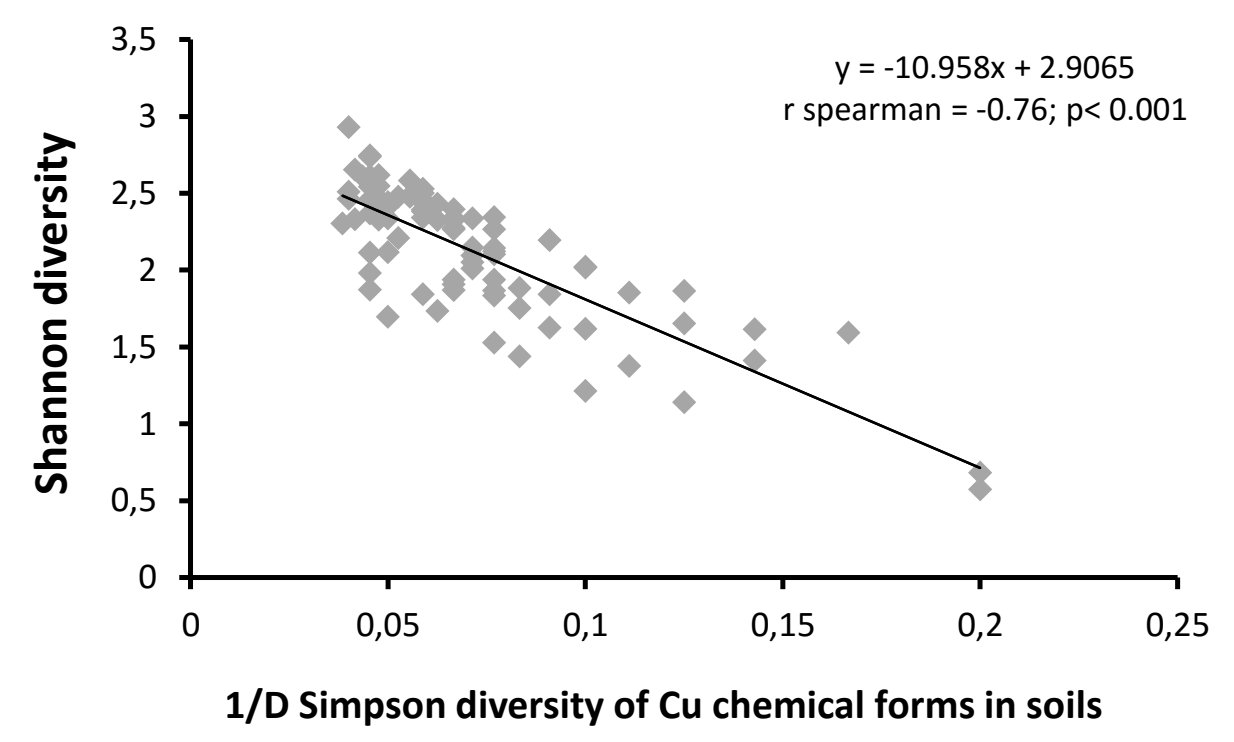

542

543 Fig. 4 Relationship between 1/D Simpson diversity ( $\mathrm{D}=$ Simpson's dominance index) of copper chemical forms 544 in soils and $\mathrm{Cu}$ Shannon diversity of higher plant species $(\mathrm{n}=83)$. Copper fractions in soils were modeled by 545 speciation modeling (WHAM 6) from method of Pourret et al. 2015.

546

547

548 


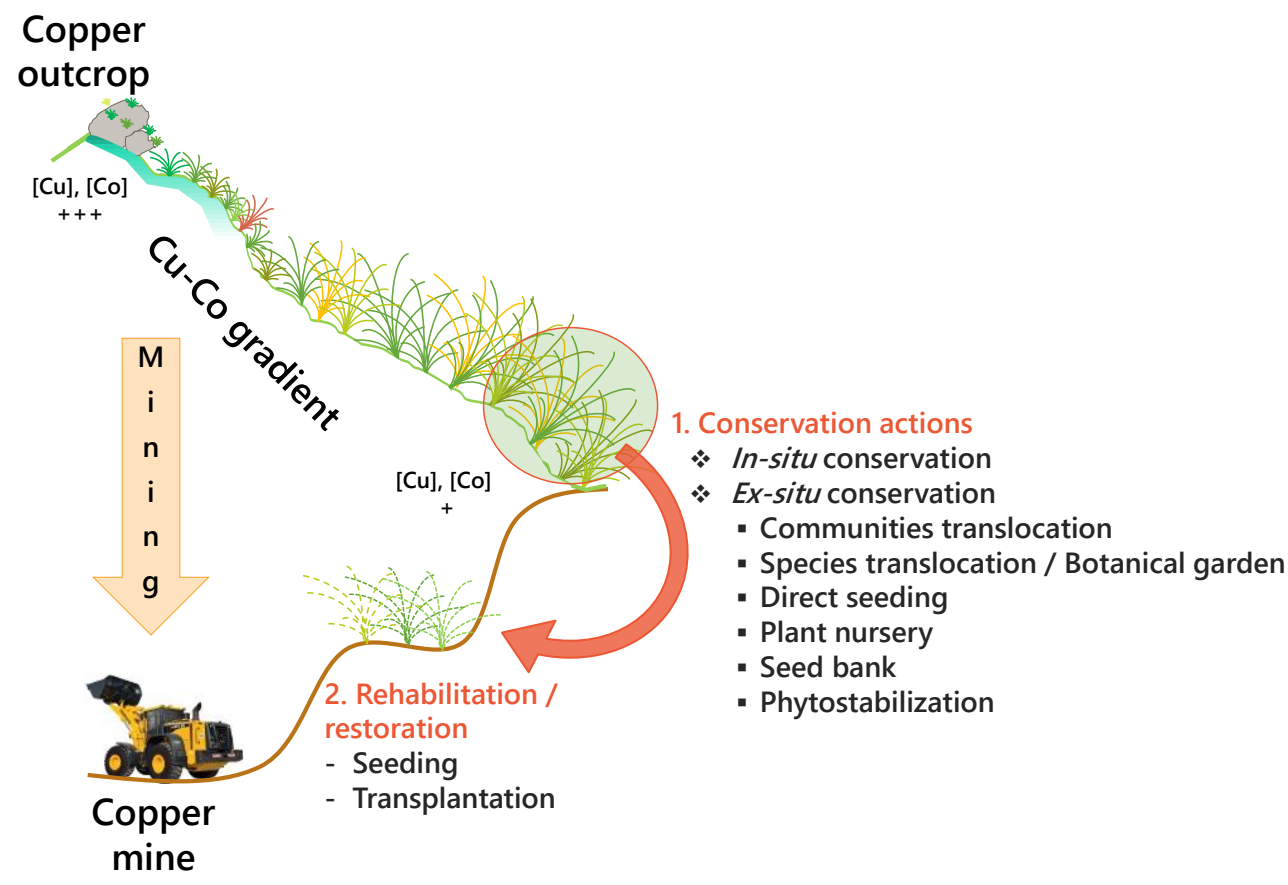

Fig. 5 Global strategy of biodiversity of natural $\mathrm{Cu}$ and Co outcrops in a mining region 